\title{
Educated unemployed youth in Manipur
}

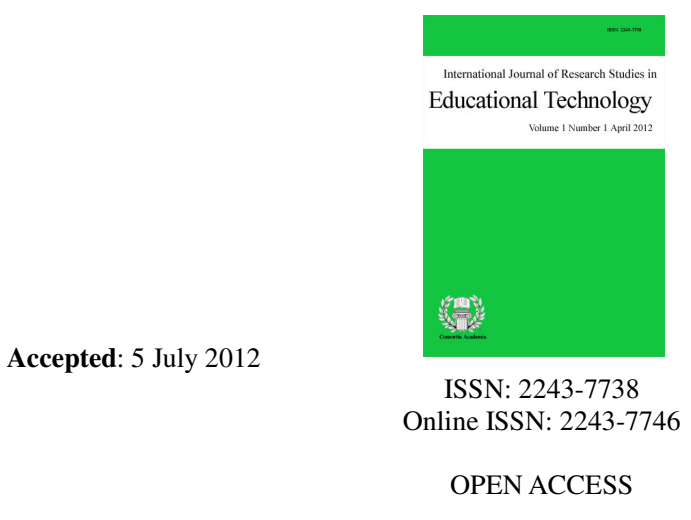

Kengoo, Kashung Zingran $\triangle$

Tata Institute of Social Sciences, New Delhi, India (kzkengoo@gmail.com)

\section{Abstract}

This article attempt to narrate the condition of providing education in Manipur which is far behind to get into the loop of practicing global educational technology that leads to socio-economic development, but instead, the state witnessed the high rate of educated unemployed youths due to indifferent skills attained by the educated youths which is not relevant in modern economical development. The educated unemployed youths among the two major sections in the state that has unequal opportunity where the dominant Manipuri (Meiteis) group had the advanced scope while the minorities (tribals) are struggling to get their share with special reference to the root causes from numerous directions will discussed. Politically, socially and economically dominant group handled most of the state administrations and divert minimally to the tribals. This article acknowledges the system of providing education, procedure for the recruitment of employee and its allied sectors that have been polluted by power, corruption, and bribe, while transparent, fairness and merits are fog in the activities of the state departments. Besides, competition and development through the techniques of educational technology is unfamiliar in the state.

Keywords: economy; literacy; workers; politicization; inequality 


\section{Educated unemployed youth in Manipur}

\section{Introduction}

Youth is a term used to denote a specific time period of people's life characterized by blooming stage in human life span, unlike the other stages of human livelihood. Theoretically, youth is measured as the middle stage of human lifelong. However, there is no universally accepted definition of youth. For operational definition, different countries, states, communities and writers have adopted different range of ages to define youth. United Nations Organization (UNO) considered the age group of (15-24) as youth. The National Youth Policy (2003) defined youth as the young people in the age group of 13-35 years. The Government of India declared the age group from (15-35) years of age as youth and it has been divided to three sub-categories; sub-junior youth contents from the age group of (15-19) years, junior youth contents from the age group of (20-24) years, and senior youth contents from the age group of (25-34) years. In general term, the age group of youth can be defined from the age of (13-35) years. Now the question arises, who are the Educated Youths? In order to answer this question in Indian context, a person who had done the schooling of eleven years from the standard of ten passed (or matriculate or equivalent) and above is termed as Educated Youths.

Educated unemployed youths consist of numerous reasons but it greatly depends on the ways of imparting education to its youths by the state and how the person achieved the skills to enhance in the workforce. The quality in achievement of educational career steers the status of employment in future of the youths. It is not only a matter of the availability and opportunity to access education but the quality of providing or imparting education. Development of the state and country strongly depends upon how the country and state provides education to its youth. In the modern global competitive world, education system is based on information technology with social relevance to education and it is flourishing in every state and country.

Imparting education without the method of technology is not relevant in modern era where varieties of technologies are applying in education to lead forth in educational progress and to translate economic development in the society. In the context of educating the youths in the country, the former President of India, A. P. J. Abdul Kalam (2012) states, "It is more about motivation, than money. It is not only about $100 \%$ educations; it is about the right kind of education. If we release the locked potential in every child, there is nothing that India cannot achieve. Creativity leads to thinking, Thinking provides knowledge, and Knowledge makes you great. India is heralded as a land of opportunity and considered among the emergent economies of the $21^{\text {st }}$ century. The greatest strength of the nation is its youth force of 600 million. If they were to stand alone, they would form the 3rd largest nation in the world. How they are shaped by education will determine the next chapter of the India story" (The Times of India, New Delhi, March 2, 2012, p. 5). Educated unemployed youth can be depicted as a person who had acquired the required stage of education but remains unemployed due to various circumstances such as unavailability of job, lack of skills, lack of industries, corruption, bribe in recruitment, financial constraints for self employment, absence of production sector, lack of resources, lack of capability, etc.

Education may be the key factor to bring development only when a person possesses the effective skills to empower in the society. If not, it demeans the value of education and it is difficult to bring economic development in the society. Chauhan (1990) described it in two ways, "Internal Efficiency" and "External Efficiency" or "Social Relevance". The efficiency of a system is judged not only by the quantity of product at the given cost, but also quality of that product. Education as an industry involves huge amounts in terms of investment. Now, the question is whether the efficiency of the system of education is satisfactory keeping in view the financial inputs. In this connection, two aspects are worth considering. First, whether or not the product (out-turn of graduates and postgraduates, etc.) of university education is up to the mark, both in terms of quality (number of pass outs) and quantity (level of academic achievement). This aspect can be called "Internal 
Efficiency" of higher education. Second, it should be examined whether the educational products (graduated, postgraduates, etc.), are equipped with skills and capabilities required by our economy, or there is a mismatch between training imparted and skills needed. It can be judged by examining the extent to which our graduates and post graduates are absorbed in job market. This aspect can be termed as "External Efficiency" or "Social Relevance" of the system (Chauhan, 1990:90). There is a huge confusion about being literate and educated. Counting high in literacy rate with quantity production of educated youth degrades the high status of education and it can be applicable in social eradication whereas economic development was mute and vain.

\section{Manipur At a Glance}

Manipur is one of the eight north eastern states in India. The state comprises of multi-ethnic, multi-linguistic and multi-religion. According to the Census of India (2001), the total population of Manipur is 22,930,896 people, out of which the tribals consist of 713,813 persons and the remaining population of 1,580,083 people forming the majority are Meiteis which include some outsiders like Nepali, Bengali, Bihari, and many others. Census of India (2001) recognized 29 tribes and there are also some unrecognized tribes in the state. The state comprises of three major communities: Meiteis, Nagas, and Kuki-Chin-Mizo. Politically, the members of the Manipur Legislative Assembly (MLA) consist of 60 seats, out of which 40 seats are represented by Meiteis (non-tribal), 19 seats are represented by Scheduled Tribes and the remaining 1 seat is represented by Meitei Scheduled Caste community. There are nine districts in Manipur: Imphal East, Imphal West, Bishnupur, and Thoubal are valley districts, dominated by Meiteis, and the hill districts, Ukhrul, Senapati, Tamenglong and Chandel are inhabited by the Nagas and Churachandpur by Kuki-Chin-Mizo group of tribes. The groups of Nagas formed majority among the tribals in the state. Hindu, Christian, Pangan (Manipuri Muslim is called Pangan), and Sanamahi (Meitei traditional religion) are the four major religions in the state. Different ethnic groups have their own distinct language/dialect, tradition and culture. The tribals have been deprived by the dominant group led government that has strike the dimension to two sections and it has impacted negatively upon the education and employment systems adversely in the state.

\subsection{Economy}

The state population is largely dependent upon agriculture sector especially, paddy field. Rice is the chief staple food of the people in the state. Majority of the Meiteis and the tribals are engaged in paddy field and other allied agricultural activities for daily livelihood as well as for commercial purpose. In the tribal inhabited hill districts, terrace cultivation (wet and dry) and jhuming cultivation or shifting cultivation (slash and burn the forest for agriculture purpose) are practiced whereas the Meitei inhabited valley areas practice terrace cultivation. Single cropping is done throughout the year while multiple cropping is not favorable due to climatic problems and scarcity of water supply in the state. Some of the major products of the state are rice, maize, potato, cauliflower, cabbage, tomato, sugar cane, pine apple, weaving cloths, garments, handicrafts, cane and bamboo craft, rearing domestic animals, pottery, honey, etc. Two kinds of fruits are largely produced seasonally throughout the year in Nagas inhabited hill districts: Orange in Tamenglong district and Lemon in Kachai village of Ukhrul district. Besides, the best qualities of clay earthen pot and its allied products are produced in Longpi village of Ukhrul district.

According to Singh (2005), "Manipur offers a tremendous scope for horticulture based economy. This sector, therefore, needs to be brought to the forefront of overall development of the state. Rice, wheat, maize, oil seeds, potato and sugarcane etc. are the main crops in the state. Among these crops, cultivation of paddy is the largest both in the plains and hills, and covers $82 \%$ of the total cultivated area. Agriculture is the mainstay of the State's economy as it engages $76 \%$ of the workers. The size of the cultivated area is, however, only $9.41 \%$ of the total geographical area of the State" (Singh, 2005, p. 39-40). There are some small scales and household level industries that can produce within the district/state level while these production industries are especially dependent upon human physical labor rather than machine tools due to lack of skills in modern technology, economic constraints and unavailability of products within the state. To apply educational technology in 
developmental activities; power supply is one of the most important ingredients while power supply is very irregular in the state. The power supply only for three hours in a day and frequently there was no power supply for a week or throughout the month. It impacted harshly upon the daily livelihood of the people and moreover, it disrupts the developmental activities very badly. The state is far backward from technological development.

\section{Division of Labor}

Historically, Meitei society was once a kingship society where the Ningthou (King) was the head among the people. After the Meitei population embraced Hinduism from their traditional religion (Sanamahi) in the eighteen century, the classification of status among the Meitei society arose according to the doctrine associated to Hindu beliefs. In hierarchical order, the higher classes enjoy the status of superiority whereas the lower classes are noted as inferior and forbidden from many social activities of which they are not eligible to enjoy the equal status like other higher classes. Unlike Meiteis, the tribals are indigenous traditional groups with similar pattern of culture, tradition and custom. Caste and class systems, which are hierarchical divisions, stratify the society based on birth and occupations are unknown to the tribals society in the state. In the case of Nagas, according to Shimray (2002), "In the classless, casteless Naga society, women have traditionally enjoyed a high social position, with a pivotal role in both family and community affairs" (Shimray, 2002, p. 375). Since the Nagas are classless society, division of labor is equal at work, in the family and society.

Likewise, the tribals follow democratic form of labor system. Every village had their particular Chief and Chief is the head of the village which is inherited from father to the eldest son of the family. Chieftainship is not transferable and it is still pertaining in the tribal villages with democratic forms of governances with slight difference in administration according to tradition and culture of the respective villages. In the context of running a family; father is the head of a family and to divide the workforce in the family, women especially, take care of household chores like children's education at home, rearing of domestic animals, fetching water, agriculture, farming, etc. Weaving is also one of the main occupations for women in tribal society for (consumption and commercial purpose). Their counterpart, men engage in trade, business, agriculture, farming, administrative and political functionaries, etc. In the modern era; whether male or female, division of labor strongly depends upon the status of educational attainment of a person.

\subsection{Types of Workers and Non-workers}

Manipur is economically a backward state. The state has witnessed the rapid rise of educated unemployed youths and it has affected negatively in the daily livelihood of the societies. Due to lack of infrastructures like transport, communication, power supply, industries, production service, shortage of capital, scarcity of credit facilities, etc. In comparison between the hill and valley districts, there is a wide gap, of which valley districts got the advance opportunities of development than the hill districts. Most of the financial institutes in the state are based in valley districts. Hill districts, except some parts of Thoubal district, falls under the category of rural areas whereas valley districts are recognized as urban areas in the state.

According to the table 1 district-wise distributions of workers in the year 2001; out of total population of 2,293,896 persons in Manipur, the state had a total number of 945,213 persons of workers, of which there were 379,705 cultivators, 113,630 agricultural laborers, 96,920 household industry workers, and 354,958 other workers. To compare between the four categories of workers in the districts of the state, Imphal West had the highest total number of 178,111 workers which is followed by Thoubal, Imphal East, and Bishnupur districts respectively. Thoubal got the highest total number of 66,854 cultivators and it was followed by Churachandpur and Ukhrul districts while the lowest number of 25,196 cultivators was seen in Bishnupur. Thoubal got the highest rate of 36,812 agricultural laborers while Imphal West attained the highest number in household industries workers and other workers with the rates of 23,844 persons and 102,538 persons. Tamenglong scores the lowest numbers in workers, agricultural laborers, household industry workers and other workers with the rates of 50,863 persons, 888 persons, 1,228 persons and 9,410 persons respectively in the state. 
Table 1

District-wise distribution of workers in Manipur 2001

\begin{tabular}{lrrrrr}
\hline State/District & Total workers & Cultivators & $\begin{array}{c}\text { Agricultural } \\
\text { Laborers }\end{array}$ & $\begin{array}{r}\text { Household } \\
\text { Industry workers }\end{array}$ & Other Workers \\
\hline Manipur & 945,213 & 379,705 & 113,630 & 96,920 & 354,958 \\
Imphal West & 178,111 & 36,094 & 15,635 & 23,844 & 102,538 \\
Imphal East & 156,882 & 31,768 & 22,371 & 23,618 & 79,125 \\
Bishnupur & 89,703 & 25,196 & 14,107 & 11,395 & 39,005 \\
Thoubal & 177,343 & 66,854 & 36,812 & 20,193 & 53,484 \\
Senapati & 71,888 & 44,766 & 9,531 & 3,454 & 14,137 \\
Tamenglong & 50,863 & 39,337 & 888 & 1,228 & 9,410 \\
Churachandpur & 99,363 & 56,107 & 8,472 & 7,043 & 27,241 \\
Chandel & 54,545 & 33,578 & 3,897 & 3,525 & 13,454 \\
Ukhrul & 66,515 & 46,005 & 1,917 & 2,620 & 15,973 \\
\hline
\end{tabular}

Source. Office of the Registrar General, Government of India. Census of India (2001).

\section{Literacy Rate in Manipur}

Literacy scenario in Manipur is much better, when we compare the percentage of literacy rate of the state with other states in the country. It is fairly higher than the national standard of literacy rate. But when it draws closer to the quality of education, the state is lacking behind in evaluating with the rest of the states of the country. Many writers, scholars and academicians accept that literacy steers social development, and lead to economic progress. But the high rate of literacy does not get translated into economic progress in the state. According to Ganguly (2004), "It must also be noted that rises in literacy levels as normally defined to mean the mere ability to read and write will not be adequate in today's Information age. Training of people in acquiring appropriate modern skills and receiving vocational education will make people economically productive" (Ganguly, 2004, p. 3). The census of India (2001) depicts that; during 1991, Manipur had a total literacy rate of 60.96 percent ( 72.98 percent males and 48.64 percent females), and it rose to 66.53 percent (80.33 percent males and 60.53 percent females) in 2001. Among the nine districts of Manipur; Imphal West held the top position by acquiring a total literacy rate of 80.61 percent ( 89.10 percent males and 72.24 percent females) in 2001 , it was followed by Imphal East with a total literacy rates of 75.38 percent $(86.44$ percent males and 66.30 percent females), Ukhrul stood in third position with the total literacy rate of 73.12 percent ( 80.13 percent males and 65.41 percent females), Bishnupur got fourth position acquiring a total literacy rate of 68.59 percent (62.25 percent males and 61.09 percent females), Thoubal attained fifth in position with a literacy rate of 66.90 percent (80.50 percent males and 55.34 percent females). The remaining four hill districts, Churachandpur, Tamenglong, Chandel, and Senapati districts had the total literacy rates of 71.96 percent, 59.33 percent, 56.86 percent and 60.60 percent respectively, whereas Senapati, Tamenglong, and Chandel districts' literacy rates were lower than the national literacy rate of 65 percent in 2001.

\subsection{Higher Educational Institutes in Manipur}

There are two central universities in Manipur: Central Agricultural University, it was established on 28 September, 1979 at Imphal, and Manipur University, established in the year 1980 at Chanchipur, Imphal. Manipur University was upgraded to Central Manipur University, in the year 2005. By 2010, there were 76 affiliated colleges to Central Manipur University, out of which there are six different types of affiliated colleges: 34 Affiliated Colleges, 18 Permanently Affiliated Private Colleges, 8 Government Aided Colleges, 7 Private Affiliated Colleges, 6 Permitted Private Colleges, and other higher educational institutions. Apart from its headquarter in Manipur, the Central Agricultural University expanded six colleges in five North East Region states with the introduction of different streams of agricultural studies in undergraduate and post-graduate levels. 
There are two medical institutes namely: Regional Institute of Medical Sciences (RIMS), established on 22 October, 1968, at Lamphelpat (Imphal), having 30 departments and 21 post-graduate subjects, and Jawaharlal Nehru Institute of Medical Sciences (JNIMS), established in the year 1989, at Porompat (Imphal). Six major Nursing Schools and Colleges were established; these nursing institutes offer Undergraduate and Diploma Courses. Besides, there are some nursing schools which offer diploma courses at high school (10) \& higher secondary school $(10+2)$ levels. Three technical institutes are Government Polytechnic (Imphal), Manipur Institute of Technology (Imphal), and Government College of Technology (Imphal). Seven Industrial Training Institutes (ITIs), with its regional headquarter situated at Imphal. The Adult Education, under the scheme of National Literacy Mission (NLM) was established in the year 1988 at Imphal, by the Government of India. Six professional Teacher Training Colleges; these teacher training colleges introduced Bachelor of Education (B.Ed.) and Master of Education (M.Ed.) Courses, and only three Law Colleges situated in Imphal, Oinam and Churachandpur. Out of the total universities, general colleges, vocational and professional institutes, only one professional college i.e. (Law College) and some general colleges are situated in hill districts.

\section{Status of the Educated Unemployed Youth}

\subsection{Population of Youths}

The table 2 depicted that; out of total population in percentage, the youths (age from 15-29 years) consist of 27.39 percent (26.84 males and 27.96 females). The combination of youths with Imphal East and Imphal West valley districts which are annexed to each other had got the highest total percentage of 122.56 percent (120.81 males and 124.31 females), which content the highest youths populations in the state. It was followed by Bishnupur, Tamenglong, Churachandpur, Chandel, Senapati, Thoubal, and Ukhrul districts.

\section{Table 2}

District-wise percentage of youth population (15-29 years) in Manipur 2001

\begin{tabular}{lrrr}
\hline \multicolumn{1}{c}{ State/District } & Males & Females & Total Percentage \\
\hline Manipur & 26.84 & 27.96 & 27.39 \\
Imphal West \& East & 120.81 & 124.31 & 122.56 \\
Bishnupur & 47.79 & 51.36 & 49.56 \\
Thoubal & 12.21 & 12.91 & 12.56 \\
Senapati & 12.53 & 13.72 & 13.10 \\
Tamenglong & 32.64 & 31.38 & 32.52 \\
Churachandpur & 31.51 & 30.95 & 31.23 \\
Chandel & 25.05 & 28.17 & 26.54 \\
Ukhrul & 11.67 & 11.13 & 11.40 \\
\hline
\end{tabular}

Source. Office of the Registrar General, Government of India. Census of India (2001).

\subsection{Educated Unemployed Youths}

The Annual Plan (2006-2007), Planning Department, Government of Manipur, the educated unemployment in Manipur has been rapidly increasing year after year (see table 3). During 1994, there were total number of 168,391 persons of educated unemployment and it was increased to 315,016 persons in 2005. Among the three educational levels; Matriculate, Under-Graduate and Graduate \& Above in the state, Matriculate got the highest number of 101,497 persons of educated unemployment in the year 1994 and the numbers were increasing year after year. It was followed by Under-Graduate level with the total number of 34,415 persons of educated unemployment in the year 1994, and increased to 75,842 persons of educated unemployment in 2005. During 1994, Graduate \& Above was the least in number of 32,479 persons of educated unemployment and it increased 
to 55,349 persons of educated unemployment in the year 2005 .

\section{Table 3}

Estimated number of educated unemployment in Manipur from 1994-2005

\begin{tabular}{lrrrr}
\hline \multicolumn{1}{c}{ Educational Level } & Year-1994 & Year-1996 & Year-1998 & Year-2005 \\
\hline Matriculate & 101,497 & 118,535 & 151,224 & 183,825 \\
Under-Graduate & 34,415 & 40,795 & 57,801 & 75,842 \\
Graduate \& Above & 32,479 & 32,363 & 48,809 & 55,349 \\
Total Educated & 168,391 & 191,693 & 257,834 & 315,016 \\
\hline
\end{tabular}

Source. The Live Register of Employment Exchange as on 30-06-2005. Annual Plan (2006-2007), Planning Department, Govt. of Manipur, December 2005, Volume I.

Table 4 depicted that, out of total 66.53 percent of literacy rate in Manipur (2001), the state attained 12.85 percent in Higher Secondary and Above with the total number of 278,328 persons. Among the districts; Imphal West got the highest rate of 22.19 percent, and it was followed by Imphal East, Bishnupur, and Thoubal districts. Ukhrul district got fifth position at the rate of 9.78 percent whereas Tamenglong district had the least of 5.51 percent. The valley districts had attained higher percentage in Higher Secondary and Above, and among the hill districts, Ukhrul scored the highest percentage. Census of India (2001) also depicted that, in Manipur, only 142 persons were taking up the streams of non-technical diploma or certificate which is not equal to degree and 2,278 persons in technical diploma or certificate not equal to degree.

\section{Table 4}

District-wise total persons and percentage of attaining higher secondary and above in Manipur-2001

\begin{tabular}{lrrrrrr}
\hline \multicolumn{1}{c}{ State/District } & Males & Females & Total Persons & Males & Females & Total Percentage \\
\hline Manipur & 168,587 & 109,741 & 278,328 & 15.39 & 10.25 & 12.85 \\
Imphal West & 55,872 & 42,723 & 98,595 & 25.19 & 19.19 & 22.19 \\
Imphal East & 36,190 & 25,044 & 61,234 & 18.24 & 12.74 & 15.51 \\
Bishnupur & 17,244 & 10,217 & 27,461 & 16.49 & 9.84 & 13.18 \\
Thoubal & 25,286 & 13,439 & 38,725 & 13.87 & 7.39 & 10.63 \\
Senapati & 5,634 & 3,010 & 8,644 & 7.02 & 3.95 & 5.52 \\
Tamenglong & 4,131 & 2,022 & 6,153 & 7.12 & 3.78 & 5.51 \\
Churachandpur & 10,686 & 5,030 & 15,716 & 9.12 & 4.54 & 6.90 \\
Chandel & 5,093 & 3,163 & 8,035 & 8.15 & 5.39 & 6.79 \\
Ukhrul & 8,672 & 5,093 & 13,765 & 11.80 & 7.56 & 9.78 \\
\hline
\end{tabular}

Source. Office of the Registrar General, Government of India. Census of India (2001).

The website of the Director of Commerce and Industries, Manipur Informatics Officer, NIC Manipur, on 7 April, 2011, states that, "A high rate of unemployment exists in Manipur, particularly among the educated youth. According to the Live Register of Employment Exchange, the total number of educated job-seekers were recorded as 583.65 thousands as on 31st March, 2007, as against 548.70 thousands as on 31st March, 2006 showing an increase of 6.37 percent over the previous year and 605.84 thousands educated job seekers were recorded as on 31st March 2008, with an increase of 3.80 percent over 2007." (Retrieved February 17, 2012, from http://investinmanipur.nic.in/gp_unemp.htm). On the other hand, according to the Report of the Department of Higher and Technical Education, Govt. of Manipur (2007), after the state-run Manipur University was upgraded to Central Manipur University in the year 2005, the tenth plan (2005-2006) approved the total outlay of Rs. 6516 lakhs (i.e. 2.32 percent from the total state annual budget) for the development of University and Higher Education in Manipur, and it was increased to Rs. 117644.90 lakhs in the year 2006-2007. It showed that, due to shortage of financial allocation, it is difficult to expand the quality of higher education in the state. 
Kengoo, K. Z.

The Report from the Directorate of Employment Exchange, Imphal (Manipur); till September 2008, the total number of educated unemployed youths in the state was 633,451 persons (459,806 males and 173,645 females). To analyze the district-wise educated unemployment youths by descending orders are as follows; Imphal West, Thoubal, Imphal East, Churachandpur, Bishnupur, Senapati, Ukhrul, Chandel, Tamenglong districts, and Physically handicapped had the lowest number of educated unemployment youths of 2354 persons in the state (see table 5). Over all, the educated unemployed youths was increased to nearly seven lakhs by the month of August 2010, with the total number of 683,454 persons of educated unemployment youths (494,456 males and 188,998 females) in the state. In modern generation, the educated unemployed youths have been increasing year after year by outnumbering the current employed youths in the state.

Table 5

Numbers of district-wise educated unemployed youths in Manipur 2010

\begin{tabular}{lrrr}
\hline \multicolumn{1}{c}{ State/District } & \multicolumn{1}{c}{ Males } & Females & Total Persons \\
\hline Manipur & 494,456 & 188,998 & 683,454 \\
Imphal West & 153,517 & 67,504 & 221,025 \\
Imphal East & 72,465 & 28,749 & 101,218 \\
Bishnupur & 45,826 & 16,056 & 62,882 \\
Thoubal & 82,792 & 21,903 & 104,695 \\
Senapati & 36,397 & 13,933 & 50,330 \\
Tamenglong & 15,668 & 4,913 & 20,581 \\
Churachandpur & 45,956 & 15,696 & 61,652 \\
Chandel & 17,232 & 7,964 & 25,196 \\
Ukhrul & 19,256 & 8,546 & 27,802 \\
Physically Handicapped & 1594 & 760 & 2,354 \\
\hline
\end{tabular}

Source. Department of Employment Exchange, Government of Manipur, August, 2012

\section{Causes of Educated Unemployed Youths}

There is a lack of quality higher educational institution that offers different kinds of global education which is based on technology. The existing general colleges in the state run the indifferent subjects which are based on traditional society; the syllabus is out-of-date to compare with the global competitive education. In fact, the state lost huge quantity of human resources which are supposed to bring economic development. Chairman and Global CEO, Core Education \& Technologies Ltd, Sanjeev Mansotra (2012) states, "We live in a world where nations increasingly must generate their own human capital allowing them to succeed in the knowledge-based work place and community. To raise the levels of human capital formation by building an innovative and competitive workforce initiating a successful STEM (Science, Mathematics, Engineering and Technology) and career technical literacy program is imperative." (The Times of India, New Delhi, June 8, 2012, p. 7). Majority of the students continue to follow up pursuing arts stream while few enrolments in sciences, commerce, mathematics, engineering, information technology and other subjects that can release the burden of economic backwardness due to non-available and low quality in functioning for the name sake. The student lacks basic knowledge in various streams of professional and vocational education because of non-existent or rareness in establishment of these types of educational institutes in the state. Besides, poverty, scarcity of career guidance and counseling centre, which is one of the most important necessary needs for the student to follow up the particular stream of education that is suitable and give interest according to the capability of the student.

Over and above; it resulted in raising the high rate of graduate-unemployment youths while in contradiction, the production of high-skill educated youths were very low in the state. Most of the educated unemployed youths acquired skills in education sector of the state do not permit them to work in the metropolitan cities where many job vacancies are available in industries, organizations, companies, corporate sectors, etc. It is due to the social irrelevant skills attained by the educated youths in the state. NPE (1986) states, "Another system of higher 
education with the same total output but producing a large proportion of indifferently educated graduates of arts, many of whom remain unemployed or are even are unemployable, could create social tensions and retard economic growth. It is only the right type of education, provided on an adequate scale that can lead to national development; when these conditions are not satisfied, the opposite effect may result" (NPE, 1986, p. 5). Application of information technology/educational technology in education system is flourishing every nook and corner of the world but the state is lacking behind from this system where education is confined mainly in theory with very limited of practical session.

\subsection{Politicization}

Most of the state government departments in the state from the highest down to the lowest levels are unseen of merit, fairness and transparency in governance. Bribery, corruption, power and money played powerful roles in order to get employment in the state or else there is no other option. The political leader and bureaucrat are the key persons to decide whom to offer vacant the post. The more amounts of cash flows into the hand of the political leader by the candidate, the better preference and opportunity to get the vacant position of the state government departments. To quote from Singh (2011), "The estimated rates for various post are discussed in private conversations range between Rs 3-4 lakh for a primary teacher, Rs 10-15 lakh for a sub-inspector/assistant SI of police, up to 15 lakh for a supervisor (women and child welfare), and Rs 15-25 lakh (or even higher) for a state civil services post." (Singh, 2011, p. 12). It has become the elite culture of the state. The educated youth with brilliant academic performance without cash and political link has no chance to get the require position. The political godfather involvement in government-run educational institutes like transferring, promotion, etc. of teachers in the inappropriate situation, without examining the condition of the particular educational institute hurt the education sector very harshly. According to the Report of The Manipur State Higher Education Commission, Part I (2003), "Many teachers get away with absenteeism, irresponsibility even with misconduct because they have political godfathers. Politicians interfere routinely in transfers and postings of Government college teachers" (Report of the Manipur State Higher Education Commission, Part I, 2003, p. 61). The problems of education and employment are fallout of a larger problem of cultural upheaval, political unrest, and socio-economic stagnation that has gripped the systems.

A public meeting was organized by the Coordinating Committee of Manipur, on 05 July 2011, in the topic of 'Free Education Zone' at Palace Compound, Imphal, in order to prevent Politicizing of Education in the State. It states in the agenda to make 'Education a Corruption Free Zone' and also the meeting also taken up the agenda of 'Exempting the Educational Institutions and Office' from the purview of any bandh or general strike. Singh (2011) states, "Education, thus, has been devalued by the government leadership for several decades. Manipur is at present driven by the power of might, force, gun and money without the rule of law. There is scant regard for education and no respect for human rights and basic needs of the people" (Singh, 2011, p. 13). The meeting was not much effective due to absence of political policy makers of the state. On the other hand, different types of militant groups in the state make monetary gain through ransom, extortion, demand cash upon educational institutions, commercial centre, state departments, etc. However, the main problem of financial governance in the state is the failure of paying monthly salary on time to the servants of the state government whereas the non-regular appointees' salary had been pending for long durations or throughout the year.

\subsection{Inequality}

Smith (2003) states, "At all levels of the education system governance is a crucial issue. The arrangements that are in place for representation and participation in consultation, decision making and governance may be potential source of conflict, or they may be opportunities for inclusion and resolution of grievances. Arrangement for transparency and accountability also reflects the system's capacity to accept and address inequalities that might otherwise become source of conflict" (Smith, 2003, p. 23). The tribals are the worse affected when one examines closely to the condition of the state. Educationally, out of the total establishment of government run educational institutes in the state, the tribal populated district, Churachandpur has got the 
highest number of six colleges, followed by Senapati with five colleges, three colleges in Chandel, Tamenglong, and Ukhrul districts have only one college each with pathetic condition of running the colleges. The Report of the Higher Education Commission (2003) also states, "The commission finds that there is a great disparity in infrastructure development between colleges in the hills and the valley and also colleges in the urban and the rural areas of the valley. This disparity has affected higher education adversely, particularly in the hills where even the basic infrastructure and the minimum teaching staff are found lacking" (Report of the Manipur State Higher Education Commission, 2003, p. viii).

The youths in valley districts are somehow getting better opportunities and they are more advance in different streams of education since, majority of the higher educational institutions are available in their vicinity and at walking distance. In hill areas, the subjects introduced were only three options Arts, Science and Commerce. Among the three subject options, the enrolments of students are very high in Arts stream whereas enrolments of students in Science and Commerce streams are very low because there were lack of educational infrastructures and shortage of qualified faculties. Likewise, the absence of Principal or Vice-Principal in the government run educational institute by deputed senior teacher as in-charge, lack of inspection, loose administration, etc. These agents deteriorated the education system and lead to null-student enrolment in Science stream, which is evident from Ukhrul Higher Secondary School (Ukhrul district), Pettigrew College (Ukhrul district), etc. which is similar to all the hill districts of the state. According to the Chairman of All-India Council for Technical Education, S. S. Mantha (2012) states, "College in remote India and institutes of poor quality are not getting students" (The Times of India, New Delhi, February 19, 2012, p. 1). In addition, the government runs professional and vocational institutes do not exist in the hill districts and all the government department headquarters are also based in valley districts where the dominant populations are employed with few minorities in the state. Therefore, it resulted in high production of educated unemployed youths in the hills district rather than valley districts.

To take a closer look at recruitment of jobs in the state government departments, the reservation of seats for tribals are not implemented equally. The apex tribals student body in Manipur, All Tribal Students' Union, Manipur, on 4 November, (2008) states, "The attitude of the Government of Manipur as well as the authorities of the university has severely marginalized the tribals, which is evident in the area of education as well as other areas too". (Retrieved January 8, 2009, from http://www.tangkhul.com/modules.php?name=News\&file=article\&sid=2807). According to the population of the state, tribal consists of 34 percent; the remaining 66 percent are Meiteis with some (migrant) outsider. The state reserved only 7.5 percent to the tribals which leads to contradiction in participation of administration and deprivation of developmental activities. It causes bitter relationship between the tribals and Meiteis within the state. The apex Nagas student body, All Naga Students' Association, Manipur and the Nagas mother organization, Naga Women's Union (2012), in Manipur against the state partiality of development, "Manipur Government also denied quality education, health services, job reservation, service promotion and infrastructural development to the tribals" (Retrieved January 18, 2012, from http://e-pao.net/GP.asp?src=3..190112.jan12). Besides, the Naga Youth Front, on 02 June 2010, also states, "In the recent recruitment of teachers under the district councils of the hills, 552 posts out of 1600 reserved vacant posts have been given to Meiteis." (Retrieved December 12, 2011, from http://www.nagalimvoice.com). The process of equal tribals participation and inclusive policy system is unfamiliar in Manipur. Vidyasagar (2007) states, "As part of the systemic crisis, this governance crisis refers to the range of political, socio, social economic and administrative systems that are in place to adjust the development and management of resources and provision of services to different communities of society. In other word it is a systemic crisis, and thus, not confined to one or more sectors as such. Obviously, the problems such as scarce and inadequate supply of educational infrastructure, inequitable distribution due to incompatible policy decisions affected the content and quantity of supply to the stakeholders. Improving the quality of this service delivery, improving reliability and equity in distribution were undeniable factors and advocating for transfer of existing centralized systems to localized clients" (Vidyasagar, 2007, p. 100-101). 


\section{Conclusion}

Due to the absence of global educational technology in the system of imparting education, it resulted in production of hefty number of educated unemployed youths that remains unemployed within the state and other places of the country where many production centers are established is the major issue in the state. The present problems of rising in educated unemployed youths in the state also represent the crisis in politics of governance from top to the bottom levels. This disaster affected badly upon the innocent youths of the state and of which the tribal youths got deeper negative impact. If youths are the pillar of tomorrow's generation, where is the scope for educated youth to bring economic development in the future generation? This poisonous system of governance can infect upon today's youths, if the educated youths follow the same path that is existing in the current state. The former President of India, A. P. J. Abdul Kalam (2012) states, "This is the real challenge. The right kind of education alone can empower our young in their toughest battle - a battle they must never stop fighting until they arrive at their destined place, that is, discover their own unique identity. And what will be the weapons to fight this battle: have a great aim in life, continuously acquire the knowledge needed to achieve it, work hard and persevere to realize your goals" (The Times of India, New Delhi, March 2, 2012, p. 5). Education relying on modern technology with social relevance is the best policy to achieve the target of one's desire as well as it can solve the economic burden.

\section{References:}

Chauhan, C. P. S. (1990). Higher education in India. New Delhi: Ashish Publishing House.

Department of Employment Exchange, Government of Manipur. (2010). Unemployment. Retrieved October 14, 2011, from http://kanglaonline.com/2010/09/unemployment-about-to-touch-7-lakh-mark/

Ganguly, J. B. (2004). Planning educational development in North East India. In L, Beloris \& D, U. Kumar (Eds.), Education in North East India: Experience and challenge (pp. 1-4). New Delhi: Concept Publishing Company.

Ministry of Human Resource Development, Department of Education. Government of India. (1986). National policy on education. New Delhi: Ministry of Human Resource Development. Office of the Registrar General, Government of India. Census Info 2001 (CD-ROM). New Delhi.

Shimray, U. A. (2002). Equity as tradition: Women's role in Naga society. Economic \& Political Weekly, 35, 375-377.

Singh, I. B. (2005). Tribals looking development: Orange and lemon festivals in Manipur. Imphal: Manipur News Publication.

Singh, N. S. (2011). State of Education in Manipur. Economic \& Political Weekly, 26, 12.

Smith, A. (2003). Education, conflict and international development. Retrieved April 5, 2008, from http://www.dfid.gov.uk/Pubs/files/edconflictdev.pdf

The Department of University and Higher Education, Government of Manipur. (2003). Report of the Manipur state higher education commission: Part I-II. Imphal: Manipur.

The Sangai Express. (2011). Public meeting decides against politicizing education. Retrieved July 5, 2011, from http://www.thesangaiexpress.com/fullstory.php?newsid=70

Vidyasagar, K. (2007). Educational 'inequality' and teachers 'performance' in Andhra Pradesh: Challenge ahead. Journal of the Council for Social Development, 37(1), 98-124. 
Kengoo, K. Z. 